\title{
Cognitive Brain Mapping Used in the Study of Entrepreneurial Behavior - Pilot Test with the Use of Electroencephalogram - EEG during the Process of Identification of Business Opportunities
}

\author{
Milton Antonio Zaro ${ }^{1, *}$, Léa da Cruz Fagundes ${ }^{2}$, Fábio Teutto Rocha ${ }^{1}$, Walter Cezar Nunes ${ }^{1}$ \\ ${ }^{1}$ Graduate Program of Computers in Education, UFRGS, Porto Alegre-RS, Brazil \\ ${ }^{2}$ Graduate Program of Electrical Engineering, FEI, São Paulo, Brazil \\ *Corresponding author: zaro@ufrgs.br
}

\begin{abstract}
Most studies on entrepreneurial behavior did not show any feasible support to the thesis that entrepreneurs are different from non-entrepreneurs. However, with the use of neuroscience techniques there was a shift from the research on entrepreneurship to other possible sources of observation. Entrepreneurship education, combined with the neuroscience interdisciplinarity, allows the use of techniques like Cognitive Brain Mapping CBM in the development of the teaching-learning process. Even though other branches of neuroscience use successfully this technique, its application in entrepreneurial behavior is a novelty in the study. This study describes the pilot test of the Cognitive Brain Mapping experimented with both established entrepreneurs and nonentrepreneurs, seeking to identify a standard behavior among neural clusters in the moments of search and discovery of business opportunities and the propensity to risk while exploring these opportunities. In this research the CBM was done with the use of the electroencephalogram (EEGq) interconnected to a computer equipped with Enscer ${ }^{\circledR}$ softwares. The neural maps of real entrepreneurs suggested that the right and left frontal areas of the brain were activated both at the time of the search and discovery of opportunities and at the time of propensity to take the risks to explore, while non-entrepreneurs showed distinct neural organizations during the two periods. The preliminary results of this research combined to similar studies developed by other researchers, in the light of neuroscience, may direct a new methodological approach in entrepreneurship education.
\end{abstract}

Keywords: neuroscience, CBM-cognitive brain mapping, search for opportunities, entrepreneurship, neuroentrepreneurship, entrepreneurial behavior

Cite This Article: Milton Antonio Zaro, Léa da Cruz Fagundes, Fábio Teutto Rocha, and Walter Cezar Nunes, "Cognitive Brain Mapping Used in the Study of Entrepreneurial Behavior - Pilot Test with the Use of Electroencephalogram - EEG during the Process of Identification of Business Opportunities." American Journal of Educational Research, vol. 4, no. 6 (2016): 472-478. doi: 10.12691/education-4-6-5.

\section{Introduction}

This pilot test about Cognitive Brain Mapping - CBM in real entrepreneurs aims to check the existence of a possible standard that interconnects the entrepreneurs' neural clusters during the two main processes identified in their inherent behavior: a) Search, discovery and exploration of opportunities; and b) Propensity to take calculated risks when making entrepreneurship decisions.

For this work there were used certain concepts established by the research methodology GEM - Global Entrepreneurship Monitor (2013), where entrepreneurs (those who generate a new entrepreneurship or enlarge some existing entrepreneurship) are classified as early entrepreneurs (growing or new) and established entrepreneurs. The early entrepreneurs or "growing entrepreneurs" are those who are involved in the structuring of a business on which no wages, management fees, or any other form of compensation were paid for more than three months. "New entrepreneurs" are the owners and administrators of a new business that paid salaries, management fees or some other form of compensation to the owners over a period of 3 to 42 months. Those classified as "established entrepreneurs" are the owners and administrators of a consolidated business that paid salaries, management fees or any other form of compensation for more than 42 months (3.5 years).

Another classification that will be important to understand is that, still based on GEM 2013, according to their motivation entrepreneurs are classified as "entrepreneurs by necessity" and "entrepreneurs by opportunity". "Entrepreneurs by necessity" are those who start an autonomous entrepreneurship because they don't have better occupation options and open a business to generate income to themselves and their families. On the other hand, "entrepreneurs by opportunity" are those who identified a business chance and decided to undertake even having other income and job alternatives. 
This study has been developed with school-leavers from IESs (Superior Teaching Institutions) in Maranhão, on the Brazilian North-East region. Maranhão has an HDI - Human Development Index of 0.639 and occupies the penultimate place among the Brazilian states.

The Brazilian North-East region is one of the most underprivileged areas of the country. Due to the low HDI Human Development Index, a large part of the population in the range 18 to 64 years old start their own business not because they foresee great business opportunities, but to meet their basic needs. In this region, $62 \%$ of the entrepreneurs earn an average income below US\$ 600.00 per month, only $4.8 \%$ have a college degree and $45.2 \%$ did not finish elementary school.

A preliminary search conducted among 383 students from several courses coming from IESs (Superior Teaching Institutions) in Maranhão in order to know their entrepreneurial profile showed that only $21 \%$ undertook new businesses, even though 96\% had expressed the will to undertake; $44.02 \%$ confirmed to have been motivated to start their own business after taking Entrepreneurship classes, but the great majority, 55.98\% did not feel any motivation.

When asked why they did not undertake, 38.56\% claimed that the reason was the lack of capital, 32.15\% said they could not identify any business opportunity, $17.64 \%$ told they were afraid of leaving the current job, $7.67 \%$ said to be waiting for the country's economical conditions to improve and 3.98\% stated other reasons.

If we include those that did not undertake due to the lack of capital (and could have taken risks by raising thirdpart capital) to those that did not foresee business opportunities and also to those who avoided risking their jobs, there is a total of $88.35 \%$ of people coming from IESs who did not undertake due to the reasons shown in the topics of this research: search and identification of opportunities and propensity to risk.

This way, it is reaffirmed the need of innovating the teaching tools so that they can enhance the students' cognitive ability in this case, especially in the higher education. In this age-group, next to the adult stage of the human development - a decisive turning-point for the individual's professional and personal life - it is fundamental not only to value their already existing knowledge but also those acquired in the school starting from the context they are inserted.

One cannot ignore the advances in research on Entrepreneurship, for severe experimental methods are used every day, more and more, to better and deeply understand the structures of the entrepreneur cognition. In this context, the cognitive neuroscience, particularly, provide us new ways to conceptualize and measure important facets in the study of entrepreneurial behavior, aiming to build unique and more effective teaching methodologies. (KRUEGER, GUNDRY, VERMA \& WILSON, 2009).

The entrepreneurial behavior can be explained by observing how entrepreneurs think according to their cognition. Initially, the research focuses on identifying personal characteristics and those differences that lead some people to recognize the opportunities and pursue them. [1,31].

Most of the studies did not show any feasible support to the thesis that these entrepreneurs are different from others, but there was a shift of research to another source of explanation - cognitive biases, i.e., a hypothesis that an entrepreneur thinks differently from non-entrepreneurs. $[2,12,14,17,19,20,30]$.

In this scenario, where the quest to understand the entrepreneurial behavior becomes one of the great challenges of the twenty-first century, scholars shed light upon the possibilities of Cognitive Neuroscience where, among multiple challenges, it is highlighted the need to respond how psychological and cognitive functions are produced in the neural circuitry. Cognitive Neuroscience seeks to emphasize on levels of analysis, ranging from the experience and behavior of individuals motivated in contexts (social level) to the information processing mechanisms that cause this phenomenon (cognitive level) up to the cerebral system in which these processes are located (neural level) [22].

Cognitive Neuroscience, together with the study of entrepreneurship, brought the concept of Neuroentrepreneurship that can be defined as the study of the entrepreneurship behavior through the utilization of tools and techniques of Cognitive Neuroscience (Figure 1). [15].

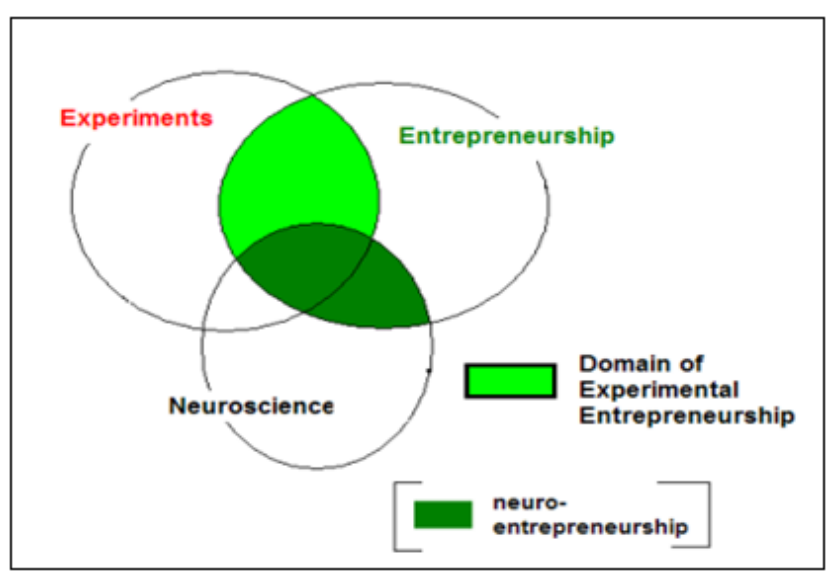

Figure 1. The domains of neuroentrepreneurship and experimental entrepreneurship [15]

Experimental methods have been little used in research about entrepreneurship, and many times it has been alleged that one cannot explore the real world behavior in an ambient of laboratory. However, current studies of neuroeconomics, neuromarketing, neuromanagement and others, clearly show the power of using experiments in neuroscience and its ramifications $[15,16]$.

Studies about entrepreneurship developed by McClelland, led him to the conclusion that, even using psychological techniques available in the research, he would need some other procedures not yet available in the entrepreneurial behavior study:

" [...] We need some more particular indication that mark the presence of a wish-fulfillment already aroused. Ideally, of course, we would be in favor of something like a "mental X-Ray" that would allow us to observe what goes on inside the head of a person, in a manner analogous to that in which we can observe the stomach contractions or nerve discharges of a starving organism [...]" [18].

The dream that guides researchers in unveiling the human machine, the codes, the signals and the circuits through which travels the vital information of human 
beings, has allowed humanity to evolve scientifically and be aware of the concept of nature and its relation to the body, its biological evolution, adaptive for the maintenance and survival of the species.[3,8,17,19,20,30].

In this scientific context, this research aims to better understand the neural responses of entrepreneurial behavior, concentrating the Cognitive Brain Mapping (CBM) in two main features observed in established entrepreneurs:

\section{a) Search for opportunities}

The search for opportunities is essential to keep alert those who are imbued with the spirit of innovation and entrepreneurship. To seek business opportunities is to get fully engaged in the process in order to discover the best ways to accomplish projects with good chances of success. The central issue in the discovery of an opportunity is to know why some people have more ability to identify opportunities than others. People who are more likely to identify opportunities are those that have more specific information and more capacity to process them. $[3,14,17,19,20,30]$.

As an empirical support to the thesis, it is known that, when presented with similar situations, entrepreneurs will have more sense of opportunity and potential gain than non-entrepreneurs. [13,25].

b) Propensity to calculated risks

Some authors say that entrepreneurs do not differ from non-entrepreneurs regarding to the propensity to risk. Rather, they react in a different way to the ambient and stimuli, especially when the figures are ambiguous. Entrepreneurs are better able to process and store ambiguous figures through cognition, thereby having a perception of scenarios involving questionable businesses more positively than those perceived by non-entrepreneurs. So, it is not their propensity to risk, but their different cognitive processes that make entrepreneurs more optimistic about a particular venture [25].

The entrepreneur takes the risks caused by changes in the market requirements. They are people that are at risk, primarily because they invest their own money in the purchase of raw material by a certain amount, process them and sell for a price not set, i.e., entrepreneurs take risks inherent in the business. [6,9,13,30,34].

\section{Research Methodology - Cognitive Brain Mapping-CMB Using EEG}

The studies were developed through a quantitative research which involved from the mathematical and statistical processing of ECG signals and the statistical inferential analysis of the volunteers' feedback, to questionnaires and a test to discover opportunities and decision-making issues in the context of entrepreneurship.

Fourteen people were surveyed in this pilot test, all of them being established entrepreneurs classified as entrepreneurs by chance, and seven non-entrepreneurs. All the fourteen people surveyed were male. Four out of seven entrepreneurs were graduated in Business Administration, two were graduated in Accounting and one in Civil Engineering. Among the non-entrepreneurs, five were graduated in Business Administration, one was graduated in Accounting and one in Computer Science. The ones who were graduated in Business Administration and
Accounting attended the Entrepreneurship \& Innovation course and the one graduated in Civil Engineering took the Organization and Management of Small Companies course. The one graduated in Computer Science took the subject on Administration \& Entrepreneurship. The entrepreneurs were in the age range of 34 years old, and the non-entrepreneurs in the range of 35.

The small sample size in studies involving tools of neuroscience has received criticism about its implementation [4]. On the other hand, in such studies, small samples show significant results due to the activation of the same brain nuclei of all participants, which might be attested in meta-analysis involving several studies over time $[5,11]$.

Individuals were accommodated in front of a computer monitor while connected to ECG electrodes, as shown in Figure 2.

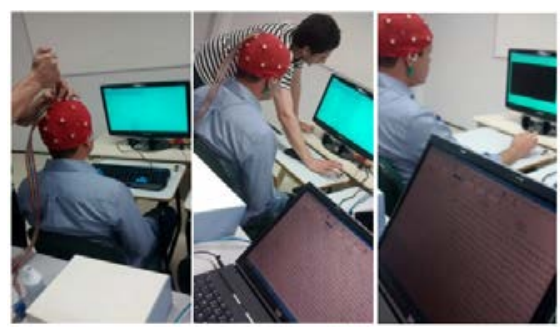

Figure 2.Volunteer during the task

All entrepreneurs were classified as "established entrepreneurs", i.e., those who manage and own a business regarded as consolidated, who paid wages, generated management fees or some other form of compensation to owners for more than 42 months (3.5 years).

\section{a. Cerebral Mapping Technique}

Considering the brain functioning model associated with the Intelligent Distributed Processing System and to the Graph Theory, we can hypothesize that the flow of (ROCHA, ROCHA, MASSAD, MENEZES, 2004; ROCHA, MASSAD, PEREIRA JUNIOR, 2005; ROCHA, MASSAD, PEREIRA JUNIOR,2005)information $h\left(c_{i}\right)$ recorded by electrode $c_{i}$ of a network such as the brain, can be measured by the entropy correlation $c_{i . j}$ between the messages exchanged between the regions of the electrode $c_{i}$ and of the other electrodes $c_{j}$.

To calculate $h\left(c_{i}\right)$ we first provide the synchronism from the moment the volunteer selects the reply option in the activity presented with the electroencephalogram recording snippet and separate the EEG times corresponding to a period of two seconds before each decision-making is carried out by the volunteer in each of the activities (Figure 3). We consider that in the two seconds prior to the decision-making the brain of the volunteer is organized in order to establish the necessary connections to the solution of the activity.

As the electrical activity log frequency is $256 \mathrm{~Hz}$, we separate 512 points in each time of the EEG. With the electric range of values recorded for each of these points, we calculate the linear correlation coefficients $c_{i . j}$ of the electrical activity recorded by each electrode $c_{i}$ referenced to the activity recorded by each of the other 19 electrodes $c_{j}$. These coefficients $c_{i . j}$ are used to calculate the entropy $h\left(c_{i . j}\right)$ for each electrode $c_{i}$ as follows:

$$
h\left(c_{i . j}\right)=-c_{i . j} \log _{2} c_{i . j}-\left(1-c_{i . j}\right) \log _{2}\left(1-c_{i . j}\right)
$$


such that $h\left(c_{i, j}\right) \rightarrow 1$ if $c_{i . j} \rightarrow 0,5$ and $h\left(c_{i . j}\right) \rightarrow 0$, otherwise.

This value represents the possibility of the electrical activity of each electrode being associated with the electrical activity of each of the other electrodes.

With these values we can calculate the entropy of the average correlation of each electrode with all other as follows:

$$
h\left(c_{i}\right)=-c_{i} \log _{2} c_{i}-\left(1-c_{i}\right) \log _{2}\left(1-c_{i}\right)
$$

such that $h\left(c_{i}\right) \rightarrow 1$ if $c_{i} \rightarrow 0,5$ and $h\left(c_{i}\right) \rightarrow 0$, otherwise.

With these values we can make up the sum of the differences between the average entropy correlation and the entropy of a given electrode with each other.

Thus, the information flow $h\left(c_{i}\right)$ in the electrode $c_{i}$ is calculated as:

$$
h\left(c_{i}\right)=\sum_{j=1}^{n} h\left(c_{i}\right)-h\left(c_{i . j}\right)
$$

We assemble a spreadsheet with a column for each electrode $c_{i}$ and fill in the lines with the entropy values generated from each period of each of the activities undertaken by each volunteer (Table 1). The data on the spreadsheet are used to generate Cognitive Brain Maps and for the analysis of network structure.

Table 1. Factor Analysis

\begin{tabular}{|c|c|c|c|}
\hline & Factor 1 & Factor 2 & Fatcor 3 \\
\hline Eigenvalues & 13,63772 & 2,015992 & 1,352399 \\
\hline C3 & 0,136845 & 0,816973 & 0,517718 \\
\hline C4 & 0,792197 & 0,430938 & 0,214824 \\
\hline CZ & 0,295376 & 0,779572 & $-0,26948$ \\
\hline F3 & 0,681121 & 0,616853 & 0,030375 \\
\hline F4 & 0,847009 & 0,407527 & $-0,00736$ \\
\hline F7 & 0,720829 & 0,481198 & 0,172189 \\
\hline F8 & 0,869291 & 0,066089 & 0,393862 \\
\hline T3 & 0,802565 & 0,369907 & 0,330954 \\
\hline T4 & 0,726464 & 0,411529 & 0,158902 \\
\hline T5 & 0,315285 & 0,300425 & 0,714932 \\
\hline
\end{tabular}

\section{b. Cognitive Brain Maps}

The exploratory multivariate analysis is used to study how $h\left(c_{i}\right)$ covaries at a given activity, grouping all times of all volunteers. If the generated factors warrant $60 \%$ or more of that covariance and have eigenvalues greater than 1 (Table 1), their respective Factor Cognitive Maps are designed with their colors illustrating the weight of the $h\left(c_{i}\right)$ of each electrode $c_{i}$ in each of the factors.

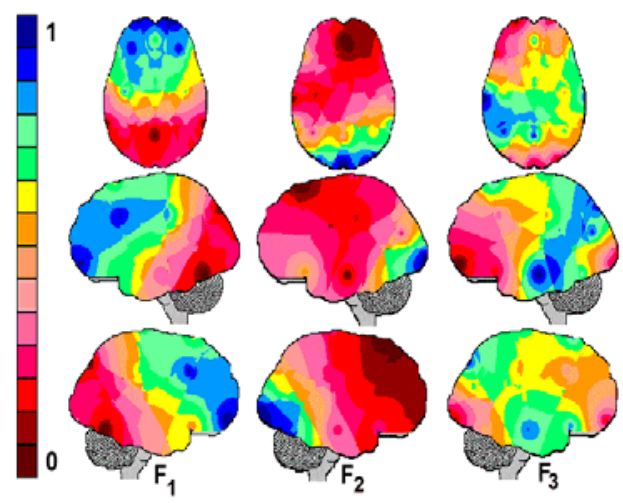

Figure 3. Cognitive Brain Maps

Starting from the resulting data, we began the analysis of the results, a report for the next chapter.

\section{Analysis of the Results}

The Cognitive Brain Mapping described on the mapping revealed 3 patterns of cortical neural connectivity, as evidenced by 3 factors with eigenvalues greater than 1 for one of our study groups. Following are the maps showing the moments when volunteers were:

A - viewing a video with jewelry pieces with wholesale prices, indicating a possible business opportunity (Searching for opportunities);

B - deciding on loan options for investment in the jewelry market (Propensity to risk in decision-making).

\subsection{Searching for Opportunities}

During the video display, the volunteers NonEntrepreneurs organized their neural connectivity in a network composed of a left frontal circuit (F1), a bilateral medial circuit (F2) and another bilateral medial left temporoparietal circuit (F3) as shown on Figure 4.

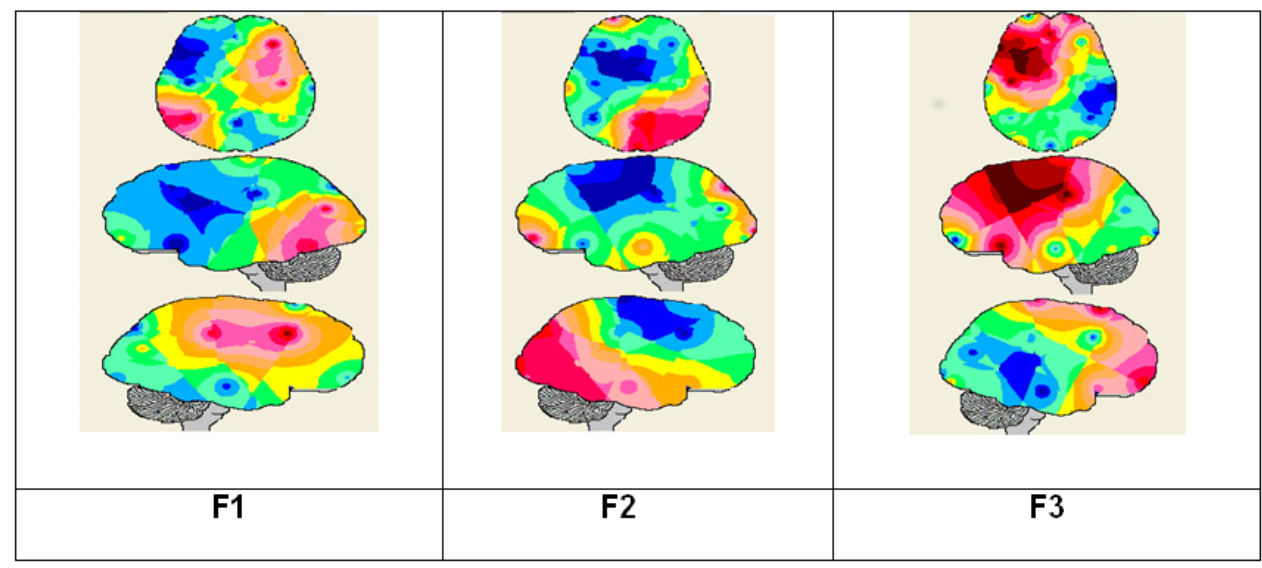

Figure 4. Cognitive Brain Maps of Non-Entrepreneurs during the search for Business Opportunities. 1st line: top view of the brain; 2nd line: view of the left hemisphere; 3rd line: view of the right hemisphere

In contrast, volunteer Entrepreneurs have shown a circuit involving frontal areas of the right hemisphere and posterior temporal areas (F1), another right frontal circuit (F2) and finally a circuit involving only two more specific 
temporal areas of the left and right hemisphere (F3), as shown on Figure 5.

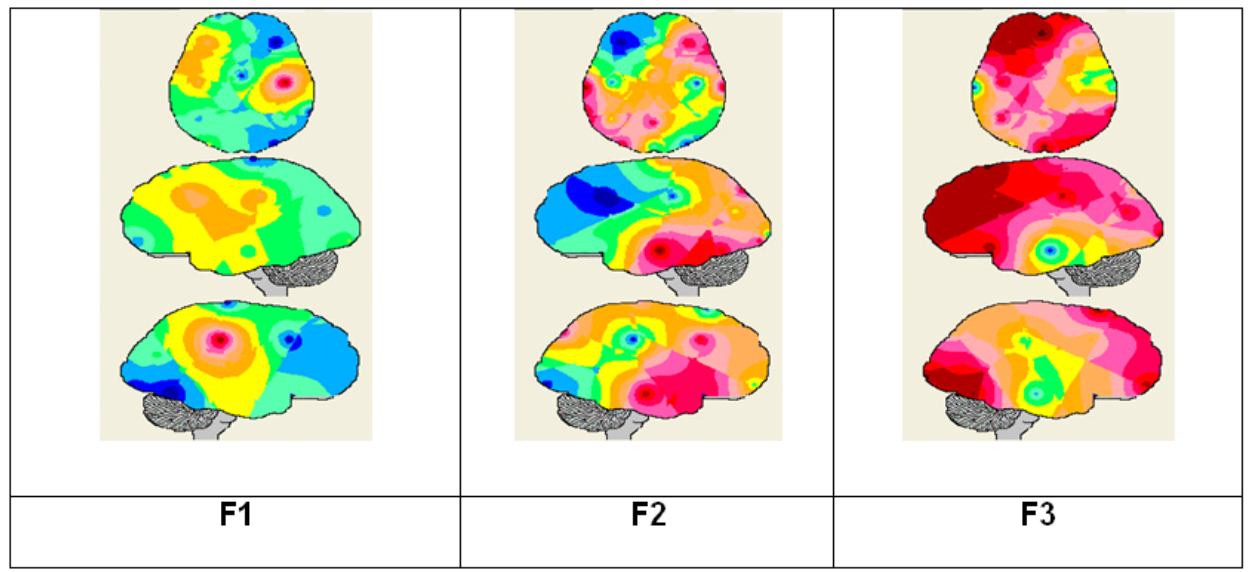

Figure 5. Cognitive Brain Maps of Entrepreneurs during the search for Business Opportunities. the left hemisphere; 3rd line: view of the right hemisphere

1st line: top view of the brain; 2nd line: view of

\subsection{Propensity to Risk}

When deciding about loan options for investment in the jewelry market, the volunteers Non-Entrepreneurs showed a stronger frontal neural circuit in the right hemisphere (F1), a bilateral posterior circuit (F2) and another more medial posterior circuit (F3), as shown on Figure 6.

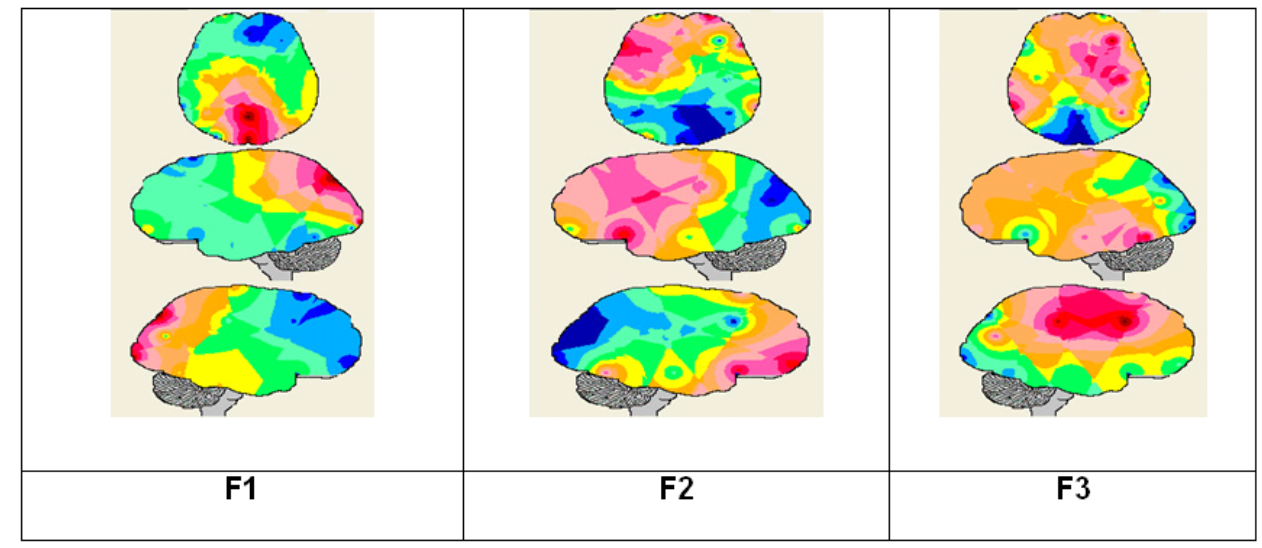

Figure 6. Cognitive Brain Maps of Non-Entrepreneurs during evaluation of Propensity to risk. left hemisphere; 3rd line: view of the right hemisphere

1st line: top view of the brain; 2nd line: view of the

Volunteer Entrepreneurs used a bilateral frontal circuit (F1) and another circuit involving only a specific front area of the right hemisphere and another medial specific area in the parietal region (F2) while the last factor (F3) does not show any clear neural circuitry, as can be seen on Figure 7.

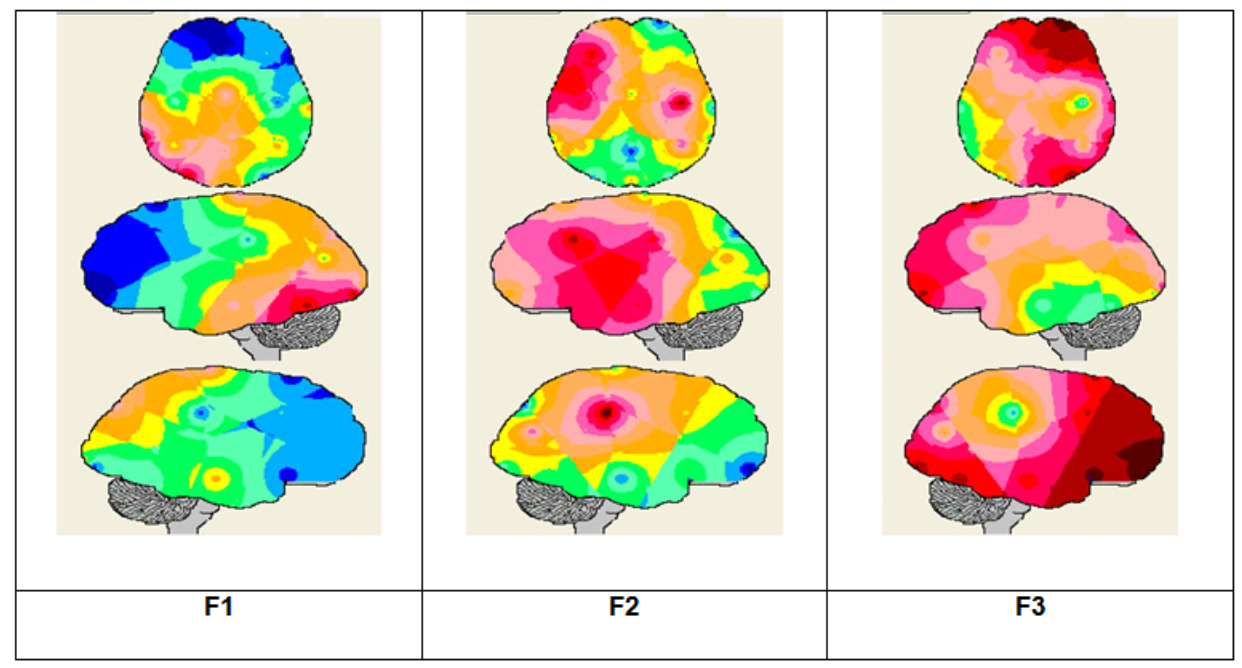

Figure 7. Cognitive Brain Maps of Entrepreneurs during evaluation of Propensity to risk. 1st line: hemisphere; 3rd line: view of the right hemisphere 


\section{Found Results and Discussion}

Watching the maps of Entrepreneurs during the two main stages of testing (video display on business opportunities and decision-making on different risk options) we see that the right frontal areas of a circuit (F1 in Figure 5) and the left frontal areas of another circuit (F2 in Figure 5) evidenced during the video with pieces of jewelry display are recruited again for the assessment of the propensity to risk, now in a single circuit (F3 in Figure 7).

On the other hand, Non-Entrepreneurs showed very different neural organizations in both situations. While this group used more frontal areas (F1 in Figure 4), medial area (F2 in Figure 4) and temporal area (F3 in Figure 4) during the display of business opportunities, they used more posterior areas (F2 and F3 in Figure 6) plus a right frontal circuit (F3 in Figure 6) during the evaluation of risk (F3 in Figure 6).

According to these results we can say that Entrepreneurs may have used the memory of the information processed during the visualization of business opportunities to calculate the risk in each of the loan options presented.

Otherwise, the Non-Entrepreneurs seem not to have considered the context presented to evaluate risk situations simulated at the end of the test. This shows us that the group of Entrepreneurs was really involved with the test in order to practice their business skills in a simulated context, and this attitude is perhaps the main difference between Entrepreneurs and Non-Entrepreneurs. While an Entrepreneur is able to consider any and all context for evaluation of financial risks, a Non-Entrepreneur will rely on a more personal context to be able to properly calculate the risks that he may or may not take.

\section{Conclusion}

The results of the CBM suggested that, on both occasions, the entrepreneurs have used cognitive activities located in the left and right frontal areas of the brain, and since the Frontal Lobe is an area involved in strategic planning, decision-making, multiple tasks accomplishment, and monitors how much interesting are the missing opportunities [21,23,24,26].

Associated with the objectives of this pilot test, the database built based on collections made on individuals through the ECG electrodes has not been explored to the fullest. This fact raises a number of prospects for the continuity of studies, including a more effective evaluation of the individuals' sensitivity in every information block, correlating these findings to the time resolution of the tasks and the emotional and motivational factors of the volunteers.

\section{References}

[1] ACS, Z., AUDRETSCH, D., DAY, M., KRUEGER, N., STANTON, A. \& WELPE, I. (2008) What can entrepreneurship learn from neurosscience? Presentation at the Academy of Management, Anaheim. Andreasen, N. (2005) Creating Brain: Neuroscience of Genius, Chicago: University of Chicago Press.
[2] BARON, R. A. W. (1998), Cognitive mechanisms in entrepreneurship: why and when entrepreneurs think differently than other people, Journal of Business Venturing, Vol. 13, pp. 275-294.

[3] BAUMOL, W.J. (1990). 'Entrepreneurship: Productive, Unproductive and Destructive', The Journal of Political Economy 98(5): 893-921.

[4] BIRNBERG, J. G. \& GANGULY, A.R., Is Neuroaccounting Waiting in the Wings? An Essay (November 16, 2011). Accounting, Organizations and Society, Forthcoming; Claremont McKenna College Robert Day School of Economics and Finance Research Paper No. 2011-05.

[5] CARVALHO JUNIOR, C.V.O, Neuroaccounting: cognitive brain mapping in operational continuity judgment. 2012. Doctoral Thesis in Controllership and Accounting - Faculty of Economics, Administration and Accounting, Universidade de São Paulo, São Paulo, 2012. Available at

$<$ http://www.teses.usp.br/teses/disponiveis 03092012-192210/. Access on 03/27/2015.

/12/12136/tde-

[6] CHRISTENSEN, P. S., O.O. MADSEN, AND R. PETERSON (1994) Opportunity identification: The contribution of entrepreneurship to strategic management, Denmark: Aarhus University Institute of Management.

[7] EINA - Estudos em Inteligência Natural e Artificial (Artificial and Natural Intelligence Studies) EEG. Available at $<$ http://www.eina.com.br/eeg_port.php>. Access on 03/27/2015.

[8] ESPINOSA, T.T.,Why Mind, Brain, and Education Scienceis the "New" Brain-Based Education. Vol. IX No. 1, Winter Journal, 2011.

[9] FILION, L. J. "Entrepreneurship: entrepreneurs and owners small business managers". 'Revista da Administração USP' magazine - april/june 1999.

[10] GEM - GLOBAL ENTREPRENEURSHIP MONITOR. Entrepreneurship in Brazil: $2013 \backslash$ Coordinated by Simara Maria de Souza, Silveira Greco; authors: Mariano Macedo Matos... [et al] -- Curitiba: IBQP, 2013, 170 p. : il.

[11] HARBAUGH, H.T. MAYR, U., BURGHART, D., et al. Neural Responses to Taxation and Voluntary Giving Reveal Motives for Charitable Donations. DOI: 10.1126/science.1140738 Science 316, 1622 (2007);William T. Harbaugh, et al.Reveal Motives for Charitable Donations.

[12] HISRICH, R. D.; PETERS I. P.; SHEPHERD, D. A. Entrepreneurship. Translated by Teresa Felix de Souza. 7ed. Porto Alegre: Bookman, 2009. 662p.

[13] IVANOVA, E. \& P. GIBCUS (2003), The decision-making entrepreneur: literature review, EIM, Zoetermeer.

[14] KIRZNER, I. (1973). Competition \& entrepreneurship (1st ed.). Chicago: University of Chicago Press.

[15] KRUEGER, N. Neuroentrepreneurship: what can entrepreneurship educators ( \& practitioners) learn from neuroscience? December, 2011. NeuroPsychoEconomics Conference Proceedings; 2011.

[16] KRUEGER, N., REILly, M., \& CARSRUD, A. (2000). Competing models of entrepreneurial intentions. Journal of Business Venturing 15(5-6), 411-432.

[17] McCLELLAND, The achievement society, Princeton, NJ: D. Van Nostrand Co., 1961.

[18] McCLELLAND, The competitive society; achievement and social progress. Translated by Álvaro Cabral. Rio de Janeiro, Expressão e Cultura, 1972.

[19] McClelland, D. C.. \& BOYATZIS, R. E. (1982). The leadership motive pattern and long-term success in management Journal of Applied Psychology, 67, 737-743.

[20] McCLELLAND, D. C, \& PILON, D. A. (1983). Sources of adult motives in patterns of parent behavior in early childhood. Journal of Personality and Social Psychology, 44, 564-574.

[21] NEUBERT, F. X, Mars RB, Thomas AG, Sallet J, Rushworth MF (2014) Comparison of human ventral frontal cortex areas for cognitive control and language with areas in monkey frontal cortex. Neuron 81(3):700-713

[22] OCHSNER, K. N., \& LIEBERMAN, M. D..The emergence of social cognitive neuroscience. In.: American Psychologist, 2001.

[23] OKUDA, J, et al. (2003). Thinking of the future and past: The roles of the frontal pole and the medial temporal lobes. Neuroimage 19(4):1369-1380.

[24] OKUDA, J., et al. (2007) Differential involvement of regions of rostral prefrontal cortex (Brodmann area 10) in time- and eventbased prospective memory. Int J Psychophysiol 64(3):233-246. 
[25] PALICH, L.E. \& BAGBY, D.R. (1995). “Using Cognitive Theory To Explain Entrepreneurial Risk-Taking: Challenging Conventional Wisdom." Journal Of Business Venturing, 10(6):425-438.

[26] PASSINGHAM, D., Wise S.P (2012) The neurobiology of the prefrontal cortex: anatomy, evolution, and the origin of insight (Oxford Univ Press, Oxford)

[27] ROCHA, F.T., ROCHA, A.F., MASSAD, E.; MENEZES, R. Brain mappings of the arithmetic processing in children and adults. Cognitive Brain Research; 2004.

[28] ROCHA, A.F., MASSAD, E., PEREIRA JUNIOR, A. The brain: from fuzzy arithmetic to quantum computing. Berlin: Springer Verlog Berlin Heidelberg; 2005.

[29] ROCHA, A. F. da; ROCHA, F.T., Neuroeconomics and decisionmaking procedure. Rio de Janeiro: LTC, 2011, 193p.
[30] SCHUMPETER, J.A. The theory of economic developmente. Oxford University Press, 1978.

[31] SHANE, S., \& VENKATARAMAN, S. (2000). The promise of entrepreneurship as a field of research. Academy of Management Review, 25(1), 217-226.

[32] SHANE, S., L, E. \& COLLINS, S. (2003) Entrepreneurial motivation, Human Resource Management Review, 13(2): 257279.

[33] SIMON, H. A. (1979) "Rational decision making in business organizations" [Nobel Memorial Lecture], American Economic Review, 69(4), September: 493-513.

[34] SIMON H.A. Rationality in Psychology and Economics. The Journal of Business, Vol. 59, No. 4, Part 2: The Behavioral Foundations of Economic Theory. (Oct., 1986), pp. S209-S224. 